\title{
Effect of Some Nutrient, Yeast Spraying and Girdling on Yield and Berry Quality of Flame Seedless Grapes
}

\author{
Abd-Elfattah, M. El-Salhy ${ }^{1}$; Saeed, S. Soliman²; Ahmed, G. Mohamed ${ }^{3}$, El Noby, H. Salem ${ }^{4}$ \\ and Milad, Z. Wadee ${ }^{2 *}$ 晋 (iD) \\ ${ }^{1}$ Pomology Department, Fac. Agric., Assiut Univ. \\ ${ }^{2}$ Natural Resources Dept., Institute of African Res. and Studies and Nile Basin Countries, Aswan Univ. \\ ${ }^{3}$ Soil and Water Dept., Fac. Agric. \& Natural Resources, Aswan Univ. \\ ${ }^{4}$ Pomology Dept., Fac. Agric. \& Natural Resources, Aswan Univ. \\ * Correspondence author
}

Received: 30/11/2021

Revised: $\quad 25 / 12 / 2021$

Accepted: 25/12/2021

Published: 30/12/2021

\begin{abstract}
To investigate the effect of sucrose, yeast and landaminezn spraying and girdling on yield and berry quality of Flame Seedless grapes. Twenty four uniformly vine was selected, as eight treatments with three replications one vine each. The study was carried out during 2019 and 2020 seasons. The experiment set up in a randomized complete block design, where, the study included The obtained results could be summarized as follows; Yield/vine and cluster weight were significantly increased due to spray either sucrose, yeast or landaminezn as well as arm girdling compared to untreated ones (control). Spraying $4 \mathrm{~g} / \mathrm{L}$ landaminezn was very effective in increasing yield and cluster weight than other treatments. Moreover, all studied treatments significantly improved the berry quality in terms of increasing berry weight, total soluble solids and anthocyanin in skin of berries and decreasing berry firmness and total acidity compared to untreated ones. The greatest results were obtained due to spraying landaminezn at 2 or $4 \mathrm{~cm}^{3} / \mathrm{L}$ where gave a high yield of good berry quality. No significant differences were obtained due to spray landaminezn at 2 or $4 \mathrm{~cm}^{3} / \mathrm{L}$, as well as yeast, sucrose or girdling. It could be concluded that spraying 2 to $4 \mathrm{~cm}^{3} / \mathrm{L}$ landaminezn to get high yield with good cluster and berry quality of Flame Seedless grapes.
\end{abstract}

Key words: Yeast, sucrose, nutrients, grapevines, girdling, quality. 


\section{Introduction}

Grapes are one of the most important fruit crops for local consumption and export. The total world area of grapes reached 7.4 million ha with a total production of 77.8 million ton fruits (57\% of wine grape , $36 \%$ of table grape , $7 \%$ of dried grape) in 2018 (OIV, 2019). In Egypt grapes are an economically important crop and cultivated area was 196905 feddan that produced about 1594781 ton of fruits a country (FAO, 2016). One of the goals of researcher is to increase the production of fruits to satisfy the requirements for local consumptions and export to foreign markets. The increase could be achieved by importing cultural practices (El-Salhy et al., 2006). Fertilization is an important and limiting factor for growth and productivity of grapevines. Among these nutrients, potassium activates enzymes that water and nutrients transport, root growth, drought and salinity resistance, biosynthesis and translocation of sugars and regulating the opening and closing of stomata (Marschner, 1995 and Dhillon et al., 1999). Phosphorus plays an important role to increase the vital functions in plants, particularly for the formation of nucleic acids biosynthesis and translocation of carbohydrate and protein synthesis (Havlin et $a l ., 2005)$. Zinc is involved in production and function of many enzymes as well as many growth hormones (Salisbury and Ross, 1992). In addition, yeast has high content of mineral particularly, $\mathrm{N}, \mathrm{P}$ and $\mathrm{K}$, proteins, vitamin $\mathrm{B}$ and natural hormone (Ferguson et al., 1987). Furthermore, sucrose improved fruit color development due to increase synthesis and accumulation of anthocyanin, these allowing earlier harvests and improving table grape quality (Gibson, 2005 and Olivares et al., 2017). Moreover, girdling and scoring will be effective techniques to improve berry quality and advance maturity in a wide variety of fruit trees (Hossain and Boyce, 2009). The beneficial effects of sucrose and yeast as well as potassium, phosphorus and zinc spraying, in addition girdling done on increasing yield and improving berry quality were emphasized by Shoaieb (2002), Poni et al. (2003), Saleh et al. (2007), Er et al. (2009), Hossain and Boyce (2009), Chang et al. (2015), Noori et al. (2018), Gouda et al., 2019 and Ahmed-Mona (2020). Therefore, the aim of this study was to investigate the benefits of sucrose, yeast and landaminezn spraying and girdling done on fruiting of Flame Seedless grapevines.

\section{Materials and Methods}

This investigation was executed through two successive seasons of 2019 and 2020 on Flame Seedless grapevines were seven years old, budded on freedom vine rootstock and grown in sandy soil under drip irrigation system, $50 \mathrm{~cm}$ between drips, in private Orchard at Al-Marashda, Qena Governorate. Vines were trained by cane method using Parron system at $2 \times 3 \mathrm{~m}$ apart, number of clusters fixed to $25 \mathrm{bunch} / \mathrm{vine}$. Twenty four vines at almost uniform in their vigor were chosen and divided into eight different treatments including the control. The eight different treatments were as follows:

1- Control (spraying water).

2- Spraying with $2 \mathrm{~g} / \mathrm{L}$ sucrose.

3- Spraying with $4 \mathrm{~g} / \mathrm{L}$ sucrose.

4- Spraying with $2 \mathrm{~g} / \mathrm{L}$ yeast.

5- Spraying with $4 \mathrm{~g} / \mathrm{L}$ yeast.

6- Spraying with $2 \mathrm{~cm}^{3} / \mathrm{L}$ Landamine Zn.

7- Spraying with $4 \mathrm{~cm}^{3} / \mathrm{L}$ Landamine Zn.

8- Girdling arms after berry softening.

Landaminezn as a nutritious solution that contains $24 \%$ potassium $\left(\mathrm{K}_{2} \mathrm{O}\right), 21 \%$ phosphorus ( $\left.\mathrm{P}_{2} \mathrm{O}_{5}\right)$ and $1.6 \%$ zinc (in chelated form). All spraying treatments were carried out after fruit set, while girdling after berry softening. Girdling was carried out by removing a narrow ring of the bark $(2 \mathrm{~mm})$ entirely around the arms. The experiment was arranged in a randomized complete block design (RCBD) with three replications, one vine per each. The following parameters were determined to evaluate the effects of different treatments on yield and berry quality during the two studied seasons.

\section{Yield components}


At the last week of May, the yield of each vine was recorded in terms of weight (in $\mathrm{kg}$ ).

\section{Cluster and berry properties}

At harvesting, three clusters per each vine were taken at random for determinations the cluster and berry traits such as cluster weight and cluster compactness coefficient. Berry quality such as berry weight, total soluble solids $\%$, reducing sugars $\%$ and total acidity $\%$ (expressed as tartaric acid per 100 $\mathrm{ml} / \mathrm{juice}$ ) berry chemical properties were determined according to A.O.A.C. (1995). In addition, Berry firmness $(\mathrm{g} / \mathrm{cm} 2)$, was recorded by using a texture analyzer instrument (Fruit Hardness Tester, No. 5101 ), as well as the anthocyanin content was determined from the standard calibration curve of cyaniding-3-glucoside as pointed out by Markham (1982). The statistical analysis of the present tabulated data was carried out according to Snedecor and Chocran (1980). Averages were compared using the new L.S.D. values at 5\% level.

\section{Results}

\section{1- Yield and cluster traits:}

Data presented in Table (1) show the effect of sucrose, yeast and landaminezn spraying as well as girdling on yield and cluster traits of Flame Seedless grapevines during 2019 and 2020 seasons. It is obvious that the results took the similar trend during the two studied seasons. As an overview, results declared that use either of landaminezn or yeast gave the heaviest yield/vine and cluster, followed by use of sucrose spraying, then girdling. This is logical, as the spraying treatments were done at the beginning of berry growth stage, while the girdling takes place after berry softening. The obtained yield/vine values were (10.59, $10.81,10.65,10.98,11.33,11.80,10.58$ \& $9.79 \mathrm{~kg} / \mathrm{vine}$ ) and cluster weight (423.7, $432.5,425.8,439.2,453.3,472.0,423.3 \&$ $391.5 \mathrm{~g}$ av. two studied seasons) due to spray, $2 \mathrm{~g} / \mathrm{L}$ sucrose, $4 \mathrm{~g} / \mathrm{L}$ sucrose, $2 \mathrm{~g} / \mathrm{L}$ yeast, $4 \mathrm{~g} / \mathrm{L}$ yeast, $2 \mathrm{~cm}^{3} / \mathrm{L}$ landaminezn, 4 $\mathrm{cm}^{3} / \mathrm{L}$ landaminezn, girdling and untreated one (control), respectively. Hence, the corresponding increment percentage of yield/vine over control was attained $(8.17$, $10.42,8.78,12.16,15.73,20.53 \& 8.07 \%$, respectively). Moreover, the results showed that there were no significant differences between the two concentrations used as well as yeast or sucrose spraying. Therefore, from an economic point of view, it could be use yeast or landaminezn at low concentration must be sprayed to produce a high yield/vine. In general look at the results, it could be seen that all treatments haven't significant effects on the number of berries of the cluster, as well as cluster length compared to untreated one (control). Hence, the treatments failed to show clear effects on cluster compactness coefficient compared to untreated one (control).

\section{2- Berry quality:}

Data of berry quality as affected by different treatments are presented in Tables ( $2 \& 3)$. Data indicated that all treatments significantly increased the berry weight compared to untreated ones (control). Spraying $4 \mathrm{~cm}^{3} / \mathrm{L}$ landaminezn gave the heaviest berries, followed by spraying with 4 $\mathrm{g} / \mathrm{L}$ yeast as compared to the control and other treatments. The obtained 25 berry weight was $(60.3,61.8,62.5,64.3,62.0$, $66.3,62.7 \& 57.0 \mathrm{~g}$ av. of the two studied seasons) due to spray sucrose at $2 \mathrm{~g} / \mathrm{L} \& 4$ $\mathrm{g} / \mathrm{L}$, yeast at $2 \mathrm{~g} / \mathrm{L} \& 4 \mathrm{~g} / \mathrm{L}$, landaminezn at 2 $\mathrm{cm}^{3} / \mathrm{L} \& 4 \mathrm{~cm}^{3} / \mathrm{L}$, girdling and control, respectively. Hence the corresponding increment percentage due to use studied treatments over untreated one (control) attained $(5.79,8.42,9.65,12.81,8.77,16.32$ $\& 10.0 \%$, respectively). Also, as the average of two studies seasons, data indicated that all treatments significantly decreased berry firmness compared to untreated one. The firmness of berries could be arranged in descending order as follows $(13.73,13.44$, $13.41,12.74,12.54,11.63$ and 11.36 as an av. of the two studied seasons, respectively) when vines were treated with $2 \mathrm{~cm}^{3} / \mathrm{L}$ landaminezn, $4 \mathrm{~cm}^{3} / \mathrm{L}$ landaminezn, $2 \mathrm{gm} / \mathrm{L}$ sucrose, $4 \mathrm{gm} / \mathrm{L}$ sucrose, girdling \& $2 \mathrm{gm} / \mathrm{L}$ yeast and the lowest at vine was treated with $4 \mathrm{gm} / \mathrm{L}$ yeast as compared with untreated 
vine $\left(14.70 \mathrm{~g} / \mathrm{cm}^{3}\right)$. Treatment with $2 \mathrm{~cm}^{3} / \mathrm{L}$ landaminezn proved to be more beneficial than the other applications. Hence, the decrement percentage of berry firmness attained $(20.88,22.72,6.50 \& 8.59 \%$ as av.

Table 1. Effect of sucrose, yeast and landaminezn spraying and girdling on yield and cluster traits of Flame Seedless grapes in 2019 and 2020 seasons.

\begin{tabular}{|c|c|c|c|c|c|c|c|c|c|}
\hline \multirow{2}{*}{$\begin{array}{l}\text { Treat- } \\
\text { ments }\end{array}$} & \multicolumn{3}{|c|}{ Yield/vine $(\mathrm{kg})$} & \multicolumn{3}{|c|}{ Cluster weight } & \multicolumn{3}{|c|}{ Cluster compactness } \\
\hline & 2019 & 2020 & Mean & 2019 & 2020 & Mean & 2019 & 2020 & Mean \\
\hline $\mathrm{T}_{1}$ & 9.33 & 10.25 & 9.79 & 373.0 & 410.0 & 391.5 & 7.27 & 6.92 & 7.09 \\
\hline $\mathrm{T}_{2}$ & 10.29 & 10.89 & 10.59 & 411.7 & 435.7 & 423.7 & 7.56 & 7.40 & 7.48 \\
\hline $\mathrm{T}_{3}$ & 10.33 & 11.29 & 10.81 & 413.3 & 451.7 & 432.5 & 7.30 & 6.79 & 7.04 \\
\hline $\mathrm{T}_{4}$ & 10.46 & 10.83 & 10.65 & 418.3 & 433.3 & 425.8 & 7.43 & 7.19 & 7.31 \\
\hline $\mathrm{T}_{5}$ & 10.75 & 11.21 & 10.98 & 430.0 & 448.3 & 439.2 & 6.79 & 7.14 & 6.96 \\
\hline $\mathrm{T}_{6}$ & 10.63 & 12.04 & 11.33 & 425.0 & 481.7 & 453.3 & 6.93 & 7.12 & 7.03 \\
\hline $\mathrm{T}_{7}$ & 11.29 & 12.31 & 11.80 & 451.7 & 492.3 & 472.0 & 7.01 & 7.53 & 7.27 \\
\hline $\mathrm{T}_{8}$ & 10.25 & 10.92 & 10.58 & 410.0 & 436.7 & 423.3 & 6.73 & 7.16 & 6.95 \\
\hline $\begin{array}{l}\text { New } \\
\text { L.S.D 5\% }\end{array}$ & 0.53 & 0.48 & 0.49 & 20.19 & 18.46 & 19.17 & NS & NS & N.S. \\
\hline
\end{tabular}

$\mathrm{T}_{1}$ : Control, $\mathrm{T}_{2}: 2 \mathrm{~g} / \mathrm{L}$ sucrose, $\mathrm{T}_{3}: 4 \mathrm{~g} / \mathrm{L}$ sucrose, $\mathrm{T}_{4}: 2 \mathrm{~g} / \mathrm{L}$ yeast, $\mathrm{T}_{5}: 4 \mathrm{~g} / \mathrm{L}$ yeast, $\mathrm{T}_{6}: 2 \mathrm{~cm}^{3} / \mathrm{L}$ landamine $\mathrm{Zn}_{\mathrm{n}}, \mathrm{T}_{7}: 4$ $\mathrm{cm}^{3} / \mathrm{L}$ landamine $\mathrm{Zn}$, T8: Girdling

of the two studied seasons) due to spray with $2 \mathrm{~g} / \mathrm{L}$ yeast, $4 \mathrm{~g} / \mathrm{L}$ yeast, $2 \mathrm{~cm}^{3} / \mathrm{L}$ landaminezn or $4 \mathrm{~cm}^{3} / \mathrm{L}$ landaminezn compared to unsprayed ones (control), respectively. Moreover, the results showed that there were no significant differences between the two concentrations used of sucrose, yeast or landaminezn as well as sucrose or girdling. In a general view, the results showed the importance of using landaminezn pre-ripening of berries. This treatment leads to production of good appearance clusters with high hardiness, which increases the marketing period and increases the price. Moreover, previous data cleared that all studied treatments significantly increased total soluble solids, reducing sugar and anthocyanin in berry skin and significantly decreased the total acidity in berry juice compared to untreated one (control). So, it could be arranged the obtained TSS values in descending order as follow $(18.00,17.75,17.37,17.00,16.60$, $16.33,15.951 \& 14.75 \%$, respectively as an av. of the two studied seasons) due to use 4 $\mathrm{cm}^{3} / \mathrm{L}$ landaminezn, $4 \mathrm{~g} / \mathrm{L}$ yeast, $2 \mathrm{~cm}^{3} / \mathrm{L}$ landaminezn, $2 \mathrm{~g} / \mathrm{L}$ yeast, $4 \mathrm{~g} / \mathrm{L}$ sucrose, girdling, $2 \mathrm{~g} / \mathrm{L}$ sucrose and untreated ones (control), respectively. Hence, the corresponding increment percentage of total soluble solids TSS was attained (22.44,
20.34, 17.76, 15.25, 12.54, 10.71\& 8.13, respectively) for using treatments compared to untreated ones (control), respectively. Moreover, the recorded anthocyanin value could be arranged in descending order as follows $(30.31,29.00,28.80,26.70,24.97$, $24.35,23.15 \& 18.31 \%$, respectively) due to use $4 \mathrm{~cm}^{3} / \mathrm{L}$ landaminezn, $4 \mathrm{~g} / \mathrm{L}$ yeast, 2 $\mathrm{cm}^{3} / \mathrm{L}$ landaminezn, $2 \mathrm{~g} / \mathrm{L}$ yeast, girdling, 4 $\mathrm{g} / \mathrm{L}$ sucrose, $2 \mathrm{~g} / \mathrm{L}$ sucrose and untreated ones (control), respectively. Hence, the corresponding increment percentage attained (64.64, 57.52, 56.44, 45.03, 35.63, $32.27 \&$ $25.75 \%$, respectively). Additionally, there are no significant differences between the two used concentration of any used materials, as well as spray with landaminezn or yeast, also, sucrose spraying, or girdling done. Therefore, from economic view, it could be recommended to spray with 2 $\mathrm{cm}^{3} / \mathrm{L}$ landaminezn or $2 \mathrm{~g} / \mathrm{L}$ yeast due to produce early grape berries with good quality.

\section{Discussion}

In a clearly sense, these treatments significantly increased all studied traits. In addition, cluster compactness coefficients were not affected. While, these treatments induce the significant decrease of juice acidity and berry firmness compared to untreated ones (control). In general, $4 \mathrm{~cm}^{3}$ 
landamine $\mathrm{Zn}, 4 \mathrm{~g}$ yeast and $2 \mathrm{~cm}^{3}$ landamine $\mathrm{Zn}$ gave the highest increasing in this respect compared to the control and other treatments. These results emphasized the importance of landaminezn spraying those contents of potassium, phosphorus and zinc. These nutrients minerals had positive effect on the growth and nutritional status of vines, thus

Table 2. Effect of sucrose, yeast and landamineZn spraying and girdling on berries traits of Flame Seedless grapes in 2019 and 2020 seasons.

\begin{tabular}{||l||c|c|c||c|c|c||c|c|c|}
\hline \multirow{2}{*}{$\begin{array}{l}\text { Treat- } \\
\text { ments }\end{array}$} & \multicolumn{3}{|c|}{ Weight 25 berries } & \multicolumn{3}{c|}{ Berries firmness(g/cm2) } & \multicolumn{3}{c|}{ T.S.S\% } \\
\cline { 2 - 11 } & 2019 & 2020 & Mean & 2019 & 2020 & Mean & 2019 & 2020 & Mean \\
\hline T1 & 56.3 & 57.7 & 57.0 & 14.61 & 14.79 & 14.70 & 14.83 & 14.67 & 14.75 \\
\hline T2 & 59.0 & 61.7 & 60.3 & 13.42 & 13.39 & 13.41 & 15.80 & 16.10 & 15.95 \\
\hline T3 & 60.3 & 63.3 & 61.8 & 12.65 & 12.83 & 12.74 & 16.40 & 16.80 & 16.60 \\
\hline T4 & 62.7 & 62.3 & 62.5 & 11.38 & 11.88 & 11.63 & 17.30 & 16.70 & 17.00 \\
\hline T5 & 64.0 & 64.7 & 64.3 & 10.91 & 11.81 & 11.36 & 18.20 & 17.30 & 17.75 \\
\hline T6 & 61.3 & 62.7 & 62.0 & 13.61 & 13.85 & 13.73 & 17.40 & 17.33 & 17.37 \\
\hline T7 & 65.0 & 67.7 & 66.3 & 13.46 & 13.42 & 13.44 & 18.23 & 18.00 & 18.12 \\
\hline T8 & 61.0 & 64.3 & 62.7 & 11.97 & 13.11 & 12.54 & 16.43 & 16.22 & 16.33 \\
\hline $\begin{array}{l}\text { New } \\
\text { L.S.D 5\% }\end{array}$ & 3.19 & 2.92 & 3.02 & 0.52 & 0.59 & 0.53 & 0.109 & 9.70 & 0.96 \\
\hline
\end{tabular}

T1: Control, T2: 2 g/L sucrose, T3: 4 g/L sucrose, T4: 2 g/L yeast, T5: 4 g/L yeast, T6: 2 cm3/L landamineZn, T7: 4 cm3/L landamineZn, T8: Girdling

increasing the yield and improving the cluster traits with good berry quality. Higher potassium supply increased TSS content and reduced total acidity of berries. Adequate potassium nutrition helps to increase the contents of berries coloring (Martin et al., 2004 and Saleh et al., 2007). Phosphorus is a major element required by plants for increasing the vital functions and cellular membranes, enzymes and energy (Havlin et al., 2005). Furthermore, zinc plays a vital part in numerous biochemical responses within the plant. It regulates the activity of several enzymes which lead to stimulation of carbohydrates, proteins and the DNA formation (Hassan et al., 2010). Zn treatments enhanced the accumulation of total soluble solids, anthocyanins in berry skin and decreasing the titratable acidity (Chang et al., 2015). The promotive effects of potassium, phosphorus and zinc using on fruiting of grapevines were emphasized by Shoaieb (2002), Poni et al. (2003), AlMashileh and Al-Rayes (2004), Saleh et al. (2007), Er et al. (2009), Noori et al. (2018), El-Badawy (2019), Abou-Zaid and Shaaban (2019) and Ahmed-Mona (2020). They concluded that using different forms of potassium, phosphorus or zinc fertilization had a positive effect on yield and berry quality different grape cultivars. In addition, yeast has high content of mineral particularly, N, P and $\mathrm{K}$, proteins, vitamin B and natural hormone, i.e., cytokinin and IAA. The improving effect of yeast application was attributed to auxins, hormones, vitamins, chelating agents and enzyme produced, which have stimulatory effects on cell division and enlargement, nutrient uptake, protein synthesis and improve net photosynthesis. These effects induced an improving of hormones and accumulation of carbohydrates consequently raising sugars and anthocyanin contents in berry induce advancing of the berry ripening (Ferguson et al., 1987 and El-Salhy et al., 2006). The results dealing with the effect of yeast spraying on grapevines fruiting are in harmony with those of Hassan (2002), Omran and Abdel-Latif (2003), Gasar et al. (2006), El-Salhy et al. (2006), Fawzi et al. (2014), El-Halaby et al. (2015), Al-Hawezy and Ibrahim (2018) and Radwan et al. (2019). They concluded that spraying yeast significantly increased the yield/vine, as well as significantly improved of berry quality in terms of increasing the berry size, TSS, reducing sugars and anthocyanin contents and decreasing the total acidity then induce advance the berry ripening. Moreover, 
sucrose improved fruit color development by increasing synthesis and accumulation of anthocyanins, thus allowing earlier harvests and improving table grape quality (Gibson, 2005 and Olivares et al., 2017). Moreover, girdling and scoring will be effective techniques to improve berry quality and advance maturity in a wide variety of fruit trees. These positive effects are due to accumulate carbohydrates in the parts above

Table 3. Effect of sucrose, yeast and landamineZn spraying and girdling on reducing sugars, acidity and anthocyanin of Flame Seedless grapes in 2019 and 2020 seasons.

\begin{tabular}{lccccccccc}
\hline \multirow{2}{*}{$\begin{array}{l}\text { Treat- } \\
\text { ments }\end{array}$} & \multicolumn{3}{c}{ Reducing sugars $\%$} & \multicolumn{3}{c}{ Acidity $\%$} & \multicolumn{3}{c}{ Anthocyanin\% } \\
\cline { 2 - 10 } T1 & 2019 & 2020 & Mean & 2019 & 2020 & Mean & 2019 & 2020 & Mean \\
\hline T2 & 11.01 & 11.87 & 11.44 & 0.670 & 0.740 & 0.705 & 18.32 & 18.50 & 18.41 \\
\hline T3 & 12.42 & 12.45 & 12.44 & 0.555 & 0.635 & 0.595 & 23.00 & 23.30 & 23.15 \\
\hline T4 & 13.07 & 13.33 & 13.20 & 0.545 & 0.560 & 0.553 & 25.10 & 23.59 & 24.35 \\
\hline T5 & 12.34 & 12.46 & 12.40 & 0.580 & 0.640 & 0.610 & 27.60 & 25.80 & 26.70 \\
\hline T6 & 14.50 & 13.57 & 14.04 & 0.550 & 0.615 & 0.583 & 30.89 & 27.10 & 29.00 \\
\hline T7 & 13.90 & 14.49 & 14.20 & 0.550 & 0.560 & 0.555 & 30.77 & 26.83 & 28.80 \\
\hline T8 & 15.22 & 14.66 & 14.94 & 0.510 & 0.525 & 0.518 & 32.40 & 28.21 & 30.31 \\
\hline New & 0.96 & 14.04 & 13.56 & 0.520 & 0.545 & 0.533 & 25.76 & 24.17 & 24.97 \\
L.S.D & & 1.08 & 0.95 & 0.059 & 0.048 & 0.055 & 2.13 & 1.91 & 1.89 \\
5\% & & & & & & & &
\end{tabular}

T1: Control, T2: $2 \mathrm{~g} / \mathrm{L}$ sucrose, T3: $4 \mathrm{~g} / \mathrm{L}$ sucrose, T4: $2 \mathrm{~g} / \mathrm{L}$ yeast, T5: $4 \mathrm{~g} / \mathrm{L}$ yeast, T6: $2 \mathrm{~cm} 3 / \mathrm{L}$ landamineZn, T7: 4 cm3/L landamineZn, T8: Girdling

the girdle and results enhance and hasten to ripen (Takayoshi and Katsutashi, 2006 and Hossain and Boyce, 2009). The result of girdling on improving berry quality of grapevines was supported by many authors such as Fawzi and Eman (2003), Omar and Girgis (2005), Abd El-Wahab (2006), Hossain and Boyce (2009), Abu-Zahra (2010), Soltekin et al. (2015) and El-Kenway (2018).

Conclusions: On the light of the current results, it could be concluded that spraying 2-4 $\mathrm{cm} 3 / \mathrm{L}$ landamineZn or $2-4 \mathrm{~g} / \mathrm{L}$ yeast to produce high yield with good cluster and berry quality for local and export markets. In addition, to avoid damages arising from errors of girdling.

Conflicts of Interest: The authors declare that they have no competing interests.

\section{References}

A.O.A.C. (1995). Association of Official Agricultural Chemists. Official Methods of Analysis. 4th ed. pp. 495-510. Benjamin Franklin Station, Washington. D.C., U.S.A.

Abd EL-Wahab, M.A. (2006). An attempt towards improving bunch quality through berry thinning and trunk girdling treatments in Black Monukka grape. J. Agric. Sci., Mansoura Univ., 31(10): 6577- 6593.

Abou-Zaid, A.A. Eman \& Shaaban, M.M. (2019). Growth, yield and berries quality in Red Roomy grapevines improved under different foliar application of Spirulina algae, zinc and boron. Middle East J. Agric. Res., 8(2): 654-661, 2019.

Abu-Zahra, T.R. (2010). Berry size of Thompson seedless as influenced by the application of gibberellic acid and cane girdling. Pak. J. Bot., 42(3): 1755-1760.

Ahmed-Mona, M.D. (2020). Enhancing fruiting of Early Sweet grape cultivar under upper Egypt climatic conditions. M.Sc. Thesis, Fac. Agric., Assiut Univ., Egypt.

Al-Hawezy, Sh.M.N. \& Ibrahim, Ch.A. (2018). Foliar Application of Bread Yeast and Organic Fertilizer to Improve Yield Quantity and Quality of Thompson Seedless Grape (Vitis vinifera L.). Journal of Germain University Vol. 5, No.2 (June 2018). 
Al-Moshileh, A., \& Al-Rayes, D. (2004, November). Effect of potassium fertilization regimes on petiole nutrient contents, yield and fruit quality of table seedless grapes. In IPI regional workshop on Potassium and Fertigation development in West Asia and North Africa (pp. 24-28).

Dhillon, W.W., Bindra, A.S. \& Brar, B.S. (1999). Response of grapes to potassium fertilization in relation to fruit yield, quality and petiole nutrient status. J. of Indian Society of Soil Sci., 47 (1): 89-94.

El-Badawy, H.E.M. (2019). Implication of using potassium and magnesium fertilization to improve growth, yield and quality of Crimson Seedless grapes (Vitis vinifera L.). J. Plant Production, Mansoura Univ., 10 (2): 133-141.

El-Halaby, E.H.S., El-Salhy, A.M., AlWasfy, M.M. \& Ibrahim, R.A. (2015). Effect of $\mathrm{GA}_{3}$, urea and yeast spraying on fruiting of Flame Seedless grapevines under sandy soil conditions. Assiut $J$. Agric. Sci., 46 (2): 95-106.

El-Kenway, M.A. (2018). Effect of spraying jasmonic acid, girdling and their combinations on growth, yield and fruit quality of Crimson Seedless grapevine. Egypt. J. Hort. 45 (1): 25-37.

El-Salhy, A.M., Marzouk, H.M. \& ElAkkad, M.M. (2006). Biofertilization and elemental sulphur effects on growth and fruiting of King's Ruby and Roomy grapevines. Egyptian J. of Horti., 33: 2944.

Er, F., Gezgin, S. \& Bayrakli, F. (2009). The effect of different zinc application methods and levels on yield and quality of hesapali (Vitis vinifera L.) grape. Bulg. J. Agric. Sci. 2009, 15, 410-416.

Fawzi, M.I.F. \& Abd EL-Moniem, Eman, A.A. (2003). Effect of girdling alone or combined with flower cluster thinning and ethephon application on fruit set, yield and quality of Black Monukka grapes. Arab Univ., J. Sci., Ain Shams Univ., Cairo, 11 (2): 733-750.
Food, F., (Food and Agriculture Organization of the United Nations), 2021. FAOSTAT: FAO Statistical Databases.http://www.fao.org/faostat/en/\# data/QCL/visualize

Fawzi, M.I.F., Haggag, L.F., Shahin, M.F.M., Merwad, M.A. \& Genaidy, E.A.E. (2014). Influence of spraying urea, born, and active dry yeast on growth, yield, leaf chemical composition and fruit quality of "Superior" Grapevines (Vitis vinifera L.) grown in sandy soil conditions. Middle East Journal of Applied Sciences. 4 (3): 740-747.

Ferguson, J.J., Auigne, W.T., Allen, L.H. \& Koch, K.E. (1987). Growth of $\mathrm{CO}_{2}$ enriched sour orange seedlings treated with gibberellic and cytokinins. Proc. Florida State Hort. Soc. 99: 37-39.

Gaser, Aisha, S.A.; A. El-Helw-Hanna and M.A. Abd EL-Wahab (2006). Effect of yeast doses and time of application on growth, yield, and fruit quality of Flame seedless grapevines. Egypt J of Appl .Sci., 21(8): 661-681.

Gibson, S.I. (2005). Control of plant development and gene expression by sugar signaling. Current Opinions in Plant Biology 8: 93-102.

Gouda, F.M., Mohamed, A.A., \& Shaaban, M.M. (2019). Abscisic acid and sucrose promote fruiting of Red Roomy grapevines under Assiut climatic conditions. Middle East Journal of Agriculture Research, 8(3): 776-781.

Hassan, A.S.A. (2002). Effect of some $\mathrm{GA}_{3}$, yeast, nitrogen, and potassium foliar spray treatments on yield, fruit quality and leaf characteristics of Thompson Seedless. Zagazig J. Agric. Res., 29 (1): 73-97.

Hassan, H.S.A., Sarrawy, S.M.A. \& Mostafa, E.A.M. (2010). Effect of foliar spraying with liquid organic fertilizer, some micronutrients and gibberellins on leaf minerals content, fruit set, yield and fruit quality of "Hollywood" plum trees. Agric. and Biology of J. of North America, 1: 638-643. 
Havlin, J. L., Beaton, J. D., Tisdale, S. L. and Nelson, W. L. (2005). Soil Fertility and Fertilizers : 7th edn.-An Introduction to Nutrient Management. Upper Saddle River, New Jersey, U. S. A.

Hossain, A.B.M.S. \& Boyce, A.N. (2009). Fig fruit growth and quality development as affected by phloem stress. Belgian. J. Agric. Sci., 15:189-195.

M.A.L.R. (2019). Ministry of Agriculture and Land Reclamation Publishes. Economic Affairs Sector.

Markham, K.P. (1982): Technique of flavonoids identification. Academic Press, London.

Marschner, H. (1995). Mineral nutrition of higher plant. Academic press, London, $4^{\text {th }}$ printing (1999): $889 \mathrm{pp}$.

Martín P., Delgado, R., González, M.R. \& Gallegos, J.I. (2004). Color of 'Tempranillo' grapes as affected by different nitrogen and potassium fertilization rates. ISHS Acta Horticulture, 652: 153-160.

Noori, A.M., Lateef, M.A.A., \& Muhsin M.H. (2018). Effect of phosphorus and gibberellic acid on growth and yield of grape (Vitis vinifera L.). Res. on Crops, 19 (4): 643-648.

OIV, (2019) International Organization of Vine and Wine Intergovernmental Organization, Statistical Report on World Viti viniculture.

Olivares, D., Contreras,C., Munoz, V., Rivera, S., Gonzalez-Aguero, M., Retamales, J. \& Defilippi, B.G. (2017). Relationship among color development anthocyanin and pigment related gene expression in Crimson Seedless grapes treated with abscisic acid and sucrose. Plant Physiol. Biochem., 115: 286-297.

Omar, A.H. \& Girgis, V.H. (2005). Some treatments affecting fruit quality of Crimson Seedless grapevine. J. Agric. Sci., Mansoura Univ., 30 (8): 4665-4673.

Omran, Y.A.M. \& Abdel-Latif, H.A. (2003). Examining of some genetically improved yeast strains on vine vigor, yield components and fruit quality of Red
Roomy grapevines. Assiut J. Agric. Sci., 34 (1): 33-42.

Poni, S., Quartieri, M. \& Tagliavini, M. (2003). Potassium nutrition of Cabernet Sauvignon grapevines (Vitis vinifera L.) as affected by shoot trimming. Plant and Soil, 253: 341-351.

Radwan, E.M.A., Khodair, O.A. \& Silem, A.A.E.M. (2019). Effect of some compounds spraying on fruiting of Superior Seedless grapevines under Assiut conditions. J. Plant Production, Mansoura Univ., 10 (1): 59-64.

Saleh, M.M.S., Ashour, N.E., El-Sheikh, M.H., \& El-Naggar, M.A.A.. (2007). Foliar sprays of potassium dihydrogen phosphate and their impact on yield, fruit quality and controlling powdery mildew disease of Thompson Seedless grapevines. American-Eurasian J. Agri. Environ. Sci. 2:133-140.

Salisbury F.B. \& Ross, C.W. (1992). Plant Physiology 4th Edition. Wadsworth Publishing Company, USA.

Shoaieb, M.M. (2002). A comparative study on the effect of soil or foliar application of potassium to Flame vines. Proc. Minia $1^{\text {st }}$ Conf. for Agric. \& Environ. Sci., Minia, Egypt. March 25-28, 2002.

Snedecor, G.W. and Cochran, W.G. (1980). "Statistical Methods", 7th ed., The Iowa State Univ. Press, U.S.A., 593 p.

Soltekin, O., Teker, T., Erdem, A., Kacar, E. \& Altindis, A.T. (2015). Response of "Red Globe" (Vitis vinifera L.) to cane girdling. BIO Web of Conferences, Volume 5, 1-4

Song, C. Z., Liu, M. Y., Meng, J. F., Chi, M., Xi, Z. M., \& Zhang, Z. W. (2015). Promoting effect of foliage sprayed zinc sulfate on accumulation of sugar and phenolics in berries of Vitis vinifera $\mathrm{cv}$. Merlot growing on zinc deficient soil. Molecules, 20(2), 2536-2554.

Takayoshi Y. \& Katsutoshi, Sh. (2006). Effects of Trunk Girdling and Crop Load Levels on Fruit Quality and Root Elongation in 'Aki Queen' Grapevines. J. Japan. Soc. Hort. Sci. 75 (6): 439-444. 
تأثير رش بعض العناصر والخميرة والتحليق علي محصول وجودة حبات العنب القليم عديم البذور

عبد الفتاح مصطفي الصالحي1، سعيد سعد سليمان2، أحمد غلاب محمد3، النوبي حفني سالم4، ميلاد زكريا وديع²

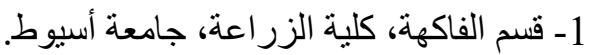

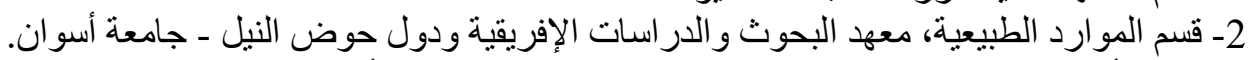

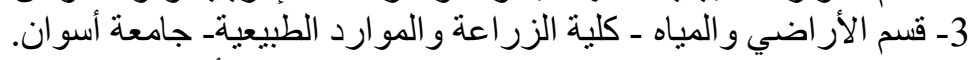

4- قسم الفاكهة، كلية الزر اعة و المو ارد الطبيعية - جامعة أسوان.

أجريت هذه الدراسة خلال موسمين متتاليين هما 2019، 2020 علي كروم العنب الفليم اللابذري المطعومة علي أصل

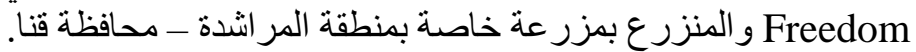

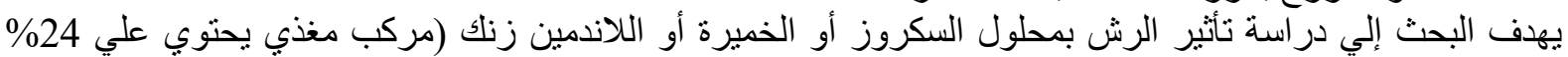

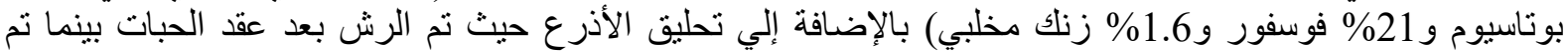

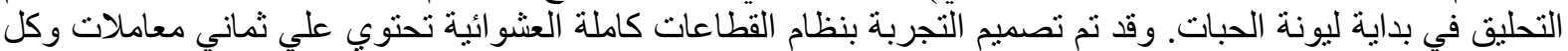

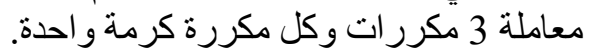
ويمكن تلخيص النتائج المتحصل مكرد عليها كالتالي:

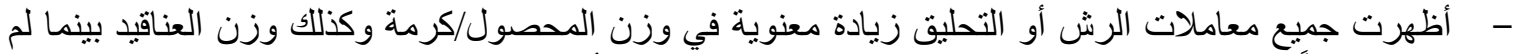
تؤثر معنوياً علي معامل تزاحم الحبات بالعنقود مقارنة بعدم الرش الرش أو أو التحليق (المقارنة).

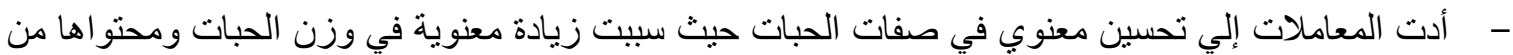
المو اد الصلبة الكلية و السكريات وصبيغة الأنثوسيانين مع نقص معنوي في في محتوى الثمار من الحموضة فئة الكلية الكية

وكذلك صلابتها مقارنة بمعاملة المقارنة.

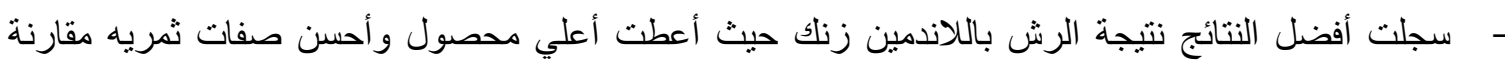
بعض المض المعلات.

- لم تسجل فروق معنوية بين رش اللاندمين زنك سواء 2 أو 4 سم//لنر. كذلك بين رش السكروز أو الخميرة أو

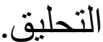

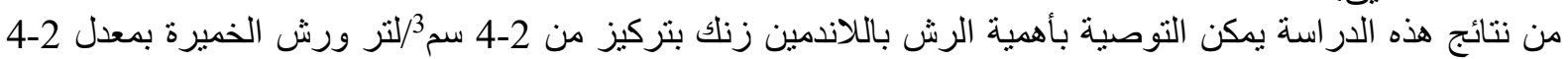

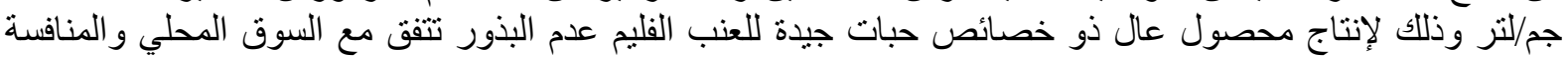

